\title{
AUTUN, Cartulaire de l'Evêché
}

Anatole de Charmasse (éd.), Cartulaire de l'évêché d'Autun connu sous le nom de cartulaire rouge publié d'après un manuscrit du XIIIe siècle, Paris-Autun , 1880.

Karl Heidecker

\section{(2) OpenEdition Journals}

Édition électronique

URL : https://journals.openedition.org/cem/2622

DOI : $10.4000 /$ cem. 2622

ISSN : 1954-3093

Éditeur

Centre d'études médiévales Saint-Germain d'Auxerre

Référence électronique

Karl Heidecker, " AUTUN, Cartulaire de l'Evêché », Bulletin du centre d'études médiévales d'Auxerre |

BUCEMA [En ligne], Collection CBMA, mis en ligne le 02 octobre 2007, consulté le 24 septembre 2022.

URL : http://journals.openedition.org/cem/2622 ; DOI : https://doi.org/10.4000/cem.2622

Ce document a été généré automatiquement le 24 septembre 2022.

\section{c) (i) (8)(2)}

Creative Commons - Attribution - Pas d'Utilisation Commerciale - Partage dans les Mêmes Conditions 4.0 International - CC BY-NC-SA 4.0

https://creativecommons.org/licenses/by-nc-sa/4.0/ 


\section{AUTUN, Cartulaire de l'Evêché}

Anatole de Charmasse (éd.), Cartulaire de l'évêché d'Autun connu sous le nom de cartulaire rouge publié d'après un manuscrit du XIIIe siècle, Paris-Autun , 1880.

\section{Karl Heidecker}

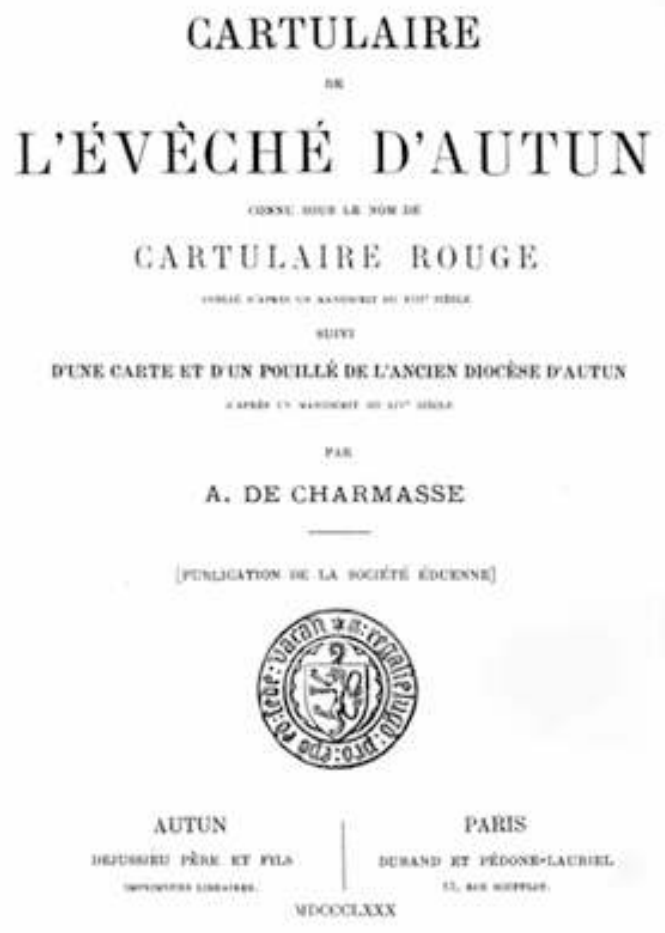

L'édition est divisée en deux parties. La première contient tous les actes d'un cartulaire du XIII ${ }^{e}$ siècle (AD Saône-et-Loire, G 0443 ; IRHT 38396; Stein 0280), dit "Cartulaire rouge". 216 actes datant des années 1143-1295 sont édités dans l'ordre du cartulaire.

Les actes ont été écrits dans ce cartulaire dans un format très souvent abrégé. Le formulaire a été abrégé, les noms propres sont désignés par une simple lettre, les noms 
des témoins sont supprimés. Aussi Charmasse a-t-il a choisi de corriger et d'éditer 64 actes d'après leurs originaux; ces actes sont désignés dans l'édition par un *. Sa transcription des contenus présente semble $t$-il peu d'erreurs (comme l'atteste l'exemplaire annoté de cette édition qui se trouve à l'IRHT d'Orléans). Signalons une erreur de référence : l'acte 215 reprend l'acte $n^{\circ} 208$ et non pas l'acte $n^{\circ} 207$.

3 La deuxième partie de l'édition contient 113 actes relatifs aux années 1109-1300 et classés en ordre chronologique. Parmi ces 113 actes, 72 ont été édités d'après leurs originaux (désignés par un ${ }^{*}$ ), 32 d'après un cartulaire volumineux du XVe siècle composé sur l'ordre de Jean Rolin (AD Saône-et-Loire, G 0445-0446 ; IRHT 38397 ; Stein 0281), dit "Cartulaire vert", et neuf d'après des copies du XVIIe siècle. La plupart des actes contenus dans le cartulaire vert avait déjà été éditée dans la première partie, d'après les originaux ou d'après le cartulaire rouge. La transcription parait être de bonne qualité.

4 Le texte de ce cartulaire est mis à disposition sur le site web d'ARTeHIS.

\section{INDEX}

Index géographique : France/Autun

Mots-clés : cartulaire, évêché 